\title{
UPGRADE OF CYBERNETICS IN THE CONTEXT OF DEVELOPING CREATIVITY
}

\author{
Inna VASYLIVNA KNYSH ${ }^{*}$ \\ National Pedagogical Dragomanov University, \\ Faculty of Management and Innovative Technologies of Socio-Cultural Activity, Department of \\ Management of Education and Science 9, Pyrohova str., Kyiv, Ukraine, 01601
}

Received 13 August 2018; accepted 18 April 2020

\begin{abstract}
The author attempted to consider upgrade of cybernetics in the context of developing creativity in modern scientific discourse. First-order cybernetics studied observed systems, secondorder cybernetics dealt with observing systems, and third-order cybernetics studied the subjectpolysubject environment - cyberspace. So, changes in the character of labour, the means of production, industrial relations and labour power have been analyzed. The article also considers the problem of "physicists and lyric poets", which prompted researchers to look for possible ways to resolve the contradictions. It resulted in the establishment of interdisciplinary connections between cybernetics and art at the non-classical stage, while at the post-non-classical stage, an interdisciplinary synthesis led to their mutually beneficial collaboration. The author uses the notion of hyphspace as metaphorical abstraction for defining a virtual reality (a component of the noosphere) that exists inside a computer network (the subject-polysubject environment). Hyphspace at the present stage of cybernetics development is becoming the basis for its subsequent (but not final) upgrade - fourth order cybernetics. Cybernetics in an interdisciplinary synthesis with art is moving from cognizing human-machine systems to the formations with growing human-dimensionality, where there is a persistent increase in the number of users-nomads.
\end{abstract}

Keywords: art, control, creativity and creativeness, cybernetics, cyberspace, hyphspace, nomads, "physicists and lyric poets", subject-polysubject environment, upgrade.

\section{Introduction}

The development of machinery, information and computer technologies (ICT), as well as their rapid involvement in all areas of life preconditioned formation of a separate branch of science, aiming at the exploration of different regulatory systems, - cybernetics, which arose in the 1940s of the 20th century. Since the appearance of first technical devices and mechanisms (machinery, automatic devices, etc.), the man has faced the problem of their management, that is, control. As to first-order cybernetics, it studied observed systems. Atomistic ideas and the analytical approach to the study of nature dominated in the research,

${ }^{\star}$ Corresponding author. E-mail: knysh_sumy@ukr.net 
because the basic objects of this rationality and the subject-object paradigm were systems (simple and complex). The total properties of their parts determined the properties of the whole, and connections that appeared due to their interaction were explained by scientific determinism, first publicly expressed by Pierre-Simon Laplace. They were homeostatic, with a functioning program that created controlling commands and corrected the action of the system based on feedbacks (Lepskij, 2012, pp. 29-35). At that time, art with such inalienable attributes as creativeness and creativity was developing separately from science, while in the intellectual environment there were taking place processes of polarization of culture, which caused contradictions between "physicists and lyric poets". Creativeness and creativity in science and art tend to manifest themselves in different ways: creative thinking, imagination, anticipation and foresight prevail in art, whereas science including cybernetics is closely bound to logical conclusions, and cause and effect relationships.

Obviously, certain upgrade of cybernetics took place: from observed systems (the object-object and the subject-object paradigms) to observing systems (the subject-subject paradigm), namely to second-order cybernetics dealing with observing systems. One of the intrinsic properties of objects was their activity, though the causality for this type of objects was not explained by scientific determinism, but was supplemented with the ideas of "target causality", which can be attributed to the category of active systems (self-developing). The specificity of the subject-object relationships in activating the object-researcher led to recognizing their limitations, focusing researchers on the paradigm of subject-subject relationships. Simultaneously, the formation of active (moreover, artistic and creative) systems as the basic type of objects to control complexity predetermined second-order cybernetics development, whereas the interdisciplinary approach became a leading one and helped to resolve the conflict between the scientists and the men of art.

But later, with the emergence of cyberspace, the subject-subject paradigm could no longer clarify the processes happening in this environment, which predetermined a further upgrade - cyberspace was being formed and, ultimately, so was the Internet (with the advent of observers - neo-nomads), that is, third-order cybernetics. The latter was studying the subject-polysubject environment - cyberspace that was not dealing with systems, but with nonlinear open formations - a network of observing systems. Consequently, its advancement caused a further interdisciplinary synthesis of humanities and natural sciences by borrowing scientific achievements, engaging cybernetics in art, and achievements of art in science (scholars started to employ quantitative methods in researching some aspects of art, which evoked a new, more rigorous comprehension of common concepts and methods). That is, creativity in humanities changed somewhat under the influence of natural sciences and humanities, and in its turn, the creative activity in natural sciences underwent changes under the influence of the humanitarian knowledge as well.

However, recently cybernetics as a part of science has undergone certain changes: cyberspace, which could be described as a rhizome before, has transformed into hyphspace, that is, fourth-order cybernetics. Hyphspace as metaphorical abstraction is, in fact, a virtual reality that is a component of the noosphere (Shestakova, 2013, p. 203). This is a completely different world, generated by a computer network with users' (neo-nomads') active involvement, who observe themselves and others as wandering around websites. This space manifests mutually 
beneficial collaboration and the exchange of information, knowledge, innovations, etc., and their active involvement and application in almost all types of human activities.

The above-mentioned considerations have predetermined the relevance of our study, the scientific novelty of which lies in the attempt to correlate the stages of the development of complexity and the control of simple and complex systems, as well as the environment (hyphspace) with the periodization of science proposed by Stepin (2003). The accentuation of these stages is grounded on the position and the meaning of the subject-observer in the background of upgrade (modernization, renewal, including both software and hardware) of cybernetics in the complexity that is advancing too fast, it is similar to Moore's law: the density of transistors in microprocessors doubles every 18-24 months (1965).

Therefore, it would be relevant to make a thorough analysis of the current cybernetics devenopment and its position in modern scientific and artistic discourse.

The purpose of the article is to analyze upgrade of cybernetics and art in the context of developing creativity in hyphspace, identifying the main distinctions in the interaction of objects, connections and processes accompanying them; to prove that cybernetics as a science, in particular due to engaging the experience and achievements of art, the ways of thinking of artists and scientists, is moving from cognition of human-machine systems to the formations with human-dimensionality and non-subjectivity.

Tasks:

1. To define the main peculiarities of development (upgrade) of cybernetics and art at classical, non-classical and post-classical stages of scientific advancement.

2. To reveal the interaction of objects, connections and processes in modern scientific discourse.

3. To analyze possible directions of cybernetics and art development at the post-nonclassical stage of science development, taking into account the revealed peculiarities.

\section{The analysis of modern research}

The research into upgrade of control of simple and complex systems, network and environment (hyhpspace) and the role of art in this process allows stating the following:

First-order systems, complex ones, were in the state of linearity (feedbacks) (Foerster, 1979; Morin, 2005; Lepskij, 2012; Bevzenko, 2002). The researchers studied the management of observed systems (in subject-object relationships) and observing systems from the position of atomistic ideas and applied an analytical approach to the study of nature. At that time, art (with its creativeness and creativity) and cybernetics were developing separately (as it has been mentioned before). Contradictions between "physicists and lyric poets", that appeared at that time, urged researchers to seek possible ways to resolve them;

Second-order systems, active ones, were in the state of nonlinearity (reflexive processes) (Foerster, 1979; Lepskij, 2012; Clausius, 1870; Maksvel, 1952; Boltzmann, 1984; Gibson 1950). The reseachers referred to statistical physics and cybernetics as studying information management and control of observing systems in the following relationships: subject-object and subject-subject that were dealing with observers. The need for reconciling "physicists and lyric poets" led to establishing interdisciplinary links between cybernetics and art; 
Third-order systems were associated with a self-developing environment (Gibson, 1984; Lepskij, 2012; Shestakova, 2013). The concept of cyberspace encompassed observing systems (subject-subject) as well as a self-developing environment (subject-polysubject) with a human's obligatary presence. At the same time, the environment inside computers (subject-object) was compared wth a radix, and the environment inside a computer network (subject-subject) with a rhizome (Deleuze \& Guattari, 1987). An interdisciplinary synthesis of science and art was progressing further due to engaging the achievements of cybernetics in art, and the gains of art in science;

Fourth-order systems comprise an environment that is self-developing in complexity with an observer-neo-nomad's involvement (Knysh, 2016, 2017a). Herewith, cyberspace is compared with the hypha with intoduction of an observer-neo-nomad, a user (users-neonomads), the subject (subjects) of cognition (human-dimensional combined network), (the subject-polysubject environment) with “a human's mandatory presence, whose integral part is a will and goal-setting” (Kochubey, 2013). At the current stage, mutually beneficial relationships between "physicists and lyric poets" are developing further.

\section{Main material presentation}

\subsection{Problems of polarization of culture at the classical stage of scientific rationality}

At the classical stage, the basic objects of scientific rationality and the subject-object paradigm were systems (simple and complex). Regarding the above-mentioned, the total properties of their parts determine the properties of the whole, and the resulting connections can be explained by Laplace's determinism. They are homeostatic and have a functioning program that creates controlling commands and corrects the action of the system based on feedbacks (Lepskij, 2012, pp. 29-35).

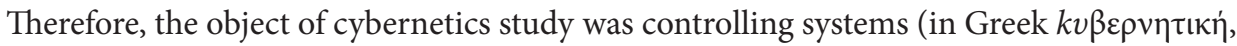
in English cybernetics, in German kybernetik - the art of the helmsman) - "the scientific study of control and communication in the animal and the machine" (Wiener, 1948). In other words, cybernetics is the science about general laws of control and accumulation, storage and transmission of information in machines (physical complexity), living organisms and society.

The French philosopher and sociologist Edgar Morin attempted to consider the historical development of machines, as well as the history of their appearance. For instance, in the work Method (originally published in 1977), volume 1 "The Nature of Nature", he noted that an artificial machine, even the latest computer, appeared from "the development of the anthropo-social machine and is only one moment and one element" of its development (Morin, 2005, p. 204).

At the early stages of society's evolution, people exploited labour power and production capabilities of "living motors" - that is, machines (animals and people). Eventually, there appeared mills: air and water; and that became a fundamentally new link between humanity and physical nature. When mechanisms and clock devices (the 13th century) went into effect, automatic mechanisms were constructed for performing more precise, fine and various operations, constructing chains repeatedly locked up in themselves; thus, in the 18th century 
the production of artificial machines began (Morin, 2005, p. 205). Consequently, together with the improvement of productive functions of automatic machines, their organizational functions were also developing, which expanded their autonomy.

As far as modern scientific discourse is concerned, it would be essential to mention that despite first-order cybernetics dealt with self-regulating control systems, the approaches to their study remained linear. Particularly, a linear mechanistic thinking comprised the foundation for first-order cybernetics (Kochubey, 2013, p. 45). Lubov Bevzenko also supports this idea,

"Classical cybernetics can be considered as one of the last pillars of scientistic thinking, oriented on the subject-object relationships of humans with the world, on subjugation of nature which seemed an irreversible consequence of scientific and technological progress" (2002, pp. 40-41).

Art was advancing in parallel with scientific knowledge, although the domains of their application did not intersect. Although first-order cybernetics studied basic objects of classical scientific rationality by applying linear approaches to their reseach and the paradigm of subject-object relationships within systems, it did not meet the requirements of non-classical scientific rationality. At the same time, as Charles Percy Snow noted, the historical peculiarities of the internal development of intellectual life brought about the polarization of culture that was known as an argument between "physicists and lyric poets", "which could not but ignite the creative spark" (1970, p. 89). Moreover, this "spark", together with other possibilities, was associated with interdisciplinarity, which accelerated that process and exacerbated other social problems in the former Soviet society (cleansing from "parasites" - lyric poets), which eventually resulted in "reconciliation" of scientists with artists. Obviously, certain upgrade of cybernetics happened: from the cybernetics of observed systems (the subject-object paradigm) to observing systems (the subject-subject paradigm). Let us consider it more thoroughly.

\subsection{An interdisciplinary synthesis of "physicists" and "lyric poets" at the non-classical stage}

The non-classical stage of science dealt with connections between knowledge about the object and the nature of means, and operations of activity in transition from the subject-object paradigm to the subject-subject paradigm. It predetermined the development of ideas about new types of controlling active systems (Burkov \& Kondratyev, 1981), such as informational (Kononov et al., 2004) and reflexive (Lefebvr, 1973), as well as the problem "means determine the object" (Lefebvr et al., 1965; Lefebvr, 1965).

Let us consider the problem of this correlation from the position of diversity and perfection. Proceeding from the first, John von Neumann testified that "complexity" at its lowest level is a phenomenon that may be fraught with degeneration. Each automatic machine capable of producing others (object-object - I. V. K.) will produce only less complex machines, although there is a certain minimal level from which this tendency to degeneration ceases to be general. Only overcoming this level makes it possible to create machines that reproduce themselves or acquire the ability to produce things that are more complex. Thus, the complexity at the level of the living being (subject-subject) is a phenomenon of either 
degeneration or the ability to grow. Living organisms reproduce themselves, that is, create new organisms without reducing the complexity. Furthermore, there are long periods of evolution, during which the complexity even increases (Nejman, 1960, p. 22); below a certain minimal level, it degenerates, and above this level, it can become self-sustaining and even acquire the ability to grow (Nejman, 1960, p. 27).

Consequently, Neumann found out that the complexity of inanimate systems (objectobject) could be viewed as a function of their diversity and the function (nonlinear) of the number of elements and subsystems. Besides, there must necessarily appear objective preconditions, in which the change in diversity (complexity) will begin to correlate with changes in the relative organization of the system. Instead, the processes of degeneration, self-sustainability or the ability to grow under objective circumstances can disclose the complexity in living systems. Moreover, the objects of the study were no longer removed from the environment of their existence; they were not divided into simple systems, but were investigated from the position of diversity in integrity and totality.

In addition to the above-mentioned, it would be relevant to dwell on Vladimir Lefebvre's concept, which he introduced in his work Conflicting Structures (originally published in 2015), where he singled out a special class of objects, which he called "objects that can be compared with the study on perfection" (Lefebvr, 1973, pp. 9-10). The researcher should reveal their "inner world" and master special means, namely, reflexive ones. At the same time, the boundary between the object and the researcher, as well as the external observer, is disrupted. Thus, the concept of "self-objectification" became commonplace for first-order rather than second-order cybernetics (Lefebvr, 1973, pp. 9-10). The distinctions between the object and the researcher disappear, since the object itself becomes a researcher (simultaneously difficulties arise when considering the researcher from the position of the object!). Subsequently, these ideas were advanced in the monograph Algebra of Conscience (originally published in 1981) (Lefebvr, 2003), in the fundamental positions of social cybernetics (Umpleby, 2016) and other scientific works.

In the article "Cybernetics of Cybernetics", the Austrian and American physicist von Foerster (1979) noted that first-order cybernetics dealt with observed systems, while second-order cybernetics is associated with observing systems, where there is a boundary between the subject and the object of control, and, as a result, between the totality of subjects and the environment, as a whole. Second-order cybernetics arose when "complex systems realized how to self-organize, to self-control and to restore biological complexity" (Motloch, 2017, p. 59).

One of the tasks of the former Soviet management system was to improve the efficiency of the economy of the totalitarian state by identifying "parasites" among the consumers of material goods - "lyric poets" and their producers - "physicists". There arose contradictions between them based on the delineation of the sphere of influence and the application of achievements. That is clearly accentuated by the literary critic Vyacheslav Polonsky,

"Science deals with concepts, while art with images. This means: science is abstract; art is concrete. Science deals with the logic world, art - with the world of feelings. Science develops laws; art builds from living flesh. In science, there are formulas, in art - forms. In science, logic prevails, in art - imagination. Science cogitates; art empathizes. Science deals with calculation, art with emotion. In science, there are 
numbers, in art - flowers. Science is dispassionate. Art, on the contrary, lives by passion. Science is rational; art is intuitive. Science lives in distractions; art, on the contrary, lives in smells, in paints, in sensations, in feelings" (1968, pp. 419-420).

Similar processes of self-organization took place in the former Soviet society when it represented an isolated system; its stability was ensured by the government's management program rather than by natural mechanisms with feedback. Therefore, random professional distortions in society could be greatly exacerbated by the incorrect strategy of the country's development. In an attempt to improve the efficiency of the economy, the government initiated a revision of citizens' participation in production of goods, which, fortunately, appeared futile since some "physicists" performed the roles of "lyric poets" in their spare time, while others badly needed to communicate with "lyric poets". Thus, an interdisciplinary synthesis between "lyric poets" and "physicists" became possible.

Summarizing all above mentioned it is possible to mention that the non-classical stage of scientific rationality with its basic subject-subject paradigm of control, an essential property of objects is their activity. However, the causality for this type of objects is not explained by scientific determinism, but is supplemented with the ideas of "target causality" that can be attributed to the category of active systems (self-developing). Society also belongs to such systems, proceeding from the experience of confrontation and reconciliation of "physicists" and "lyric poets". The specificity of the subject-subject relationships with activating the objectresearcher led to the recognition of their limitations, focusing researchers on the subjectsubject paradigm (biological complexity). At the same time, the formation of active systems as a basic type of controlling objects predetermined second-order cybernetics development, when the leading approach became interdisciplinary. Nevertheless, later, with the emergence of such formation as cyberspace, the subject-subject paradigm could no longer explain the processes occurring in this environment, which gave rise to the post-classical scientific rationality. Cybernetics upgraded further - cyberspace was being formed and, finally, the Internet was invented (with the advent of observers-nomads).

Gradually, the concept of complexity was complemented with discoveries in the field of statistical physics, kinetic theory of gases (as the ratio of complexity and organization) and cybernetics (the concept of hierarchy and the idea of the level organization of systems). With the onset of machines' self-reproduction and the involvement of the man (neo-nomad) in cyberspace, the researchers faced a problem of controlling processes that take place in parallel in machine-machine (object-object), human-machine (subject-object) systems, and the subject-subject environments. Consequently, cybernetics is moving from cognition of human-machine systems to formations where "the presence of a human, his will and goalsetting comprise an integral part" (Kochubey, 2013, p. 55), that is, in cybernetics of higher order we have to observe precisely these processes.

\subsection{Cybernetics and art: problems and prospects for their beneficial collaboration in hyperspace at the post-non-classical stage}

Post-non-classical cybernetics is associated with ideas of cyberspace, which has been undergoing significant changes. For that reason, it would be appropriate to specify this term with a few definitions. The Canadian science fiction writer Gibson, known as the "father of cy- 
berpunk", was the first to propose the concept of "cyberspace" in his short story "Burning Chrome" (1982). Later, in his novel Neuromancer (1984) he formulated the definition of cyberspace as "a consensual hallucination experienced daily by billions of legitimate operators in every nation" (Gibson, 1984, p. 309). Therefore, a global network is a "consensual hallucination", cyberspace beyond which there are no points (cities, museums, libraries, etc.) that we virtually visit, instead there are only lines - communication channels (communications), which join Web pages requested by users. In its original meaning, "cyberspace" involves users but only as subjects of cognition.

Cyberspace is also defined as metaphorical abstraction used in philosophy and in computer technologies, a (virtual) reality representing the noosphere (Shestakova, 2013, p. 203). Namely, it is another world that exists "inside" computers as well as "nside" a computer network.

Summarizing the aforementioned definitions it is possible to state that cyberspace, as the subject-polysubject environment, is a consensual hallucination of subjects in the world of a computer network as subjects of cognition. As syberspace is studied by third-order cybernetics, its difference from previous stages lies in the fact that the subject of its study is no longer a system but a network. Deleuze and Guattari (1987) emphasize this peculiarity of the network in the chapter "Introduction: The Rhizome" of their fundamental work $A$ Thousand Plateaus: Capitalism and Schizophrenia. Viewed as an autonomous module, outside its connections with others, the computer itself cannot be a rhizomatic entity, since it was designed as a specific hierarchical structure where "power is granted to a memory or central organ" (Deleuze \& Guattari, 1987, p. 16). As for third-order cybernetics, it does not deal with systems but with a nonlinear open formation, the network of observing systems. Third-order cybernetics appeared when "consciousness learned to integrate all complex adaptive systemic intellects (environmental, artificial, etc.) in order to withstand and restore the complexity of a complex adapted system" (Motloch, 2017, p. 59). However, lately third-order cybernetics has also undergone some changes: the cyberspace, which could be interpreted as a rhizome, has modified transforming into hyphspace, namely, it has been expanding its boundaries to the size of environments. Deleuze and Guattari (1987) considered a limited network of machines with communication made from one subject to another as a prototype of a rhizomatic plurality with horizontal (inter-species) and planar connections. Routes are not defined in advance, and all participants are interchangeable, so coordination of local operations and synchronization of the final overall result is achieved without the central organ (Deleuze \& Guattari, 1987), which is, in our opinion, characteristic of the "radix" (Knysh, 2016, p. 159) a sederant operating either in a simple or complex system.

Here we can notice a metaphorical discrepancy. In order to prove this, it would be appropriate to refer to the following interpretations.

Rhizome (in Greek pi $\zeta \omega \mu \alpha$, rhizoma - root, rootstock) is a subterranean big or small perennial plant shoot; serves for deposit of reserve substances, vegetative reproduction and propagation; has scale-like leaves, scars, buds and adventitious roots; form ramified systems; the old parts of rhizomes gradually decay (Biologicheskij slovar' on-line 2018). At the same time, a rhizome maintains both horizontal (inter-species) and planar connections. 
Thus, a rhizome is a means of denoting a radical alternative to closed and static linear structures, which involves a rigid axial orientation. Such structures are semantically interconnected with the fundamental (for the classical European culture) metaphor of the root, differentiating between its own root and taproot systems (a root), on the one hand, and fibrous, or bud-shaped systems (a rootlet), on the other one. In contrast to any kind of root organization, a rhizome is interpreted as a tuber or bulb rather than a linear axis, which is entirely different from a root, as a potential infinity containing a hidden stem. The potential difference lies in the fact that this stem can develop anywhere and create any configuration, whereas a rhizome is nonlinear. "The world has lost its axis" (Deleuze \& Guattari, 1987, p. 11).

The fundamental property of a rhizome is its heteronomy while maintaining integrity. It is

"a semiotic link, like a bulb, in which the most diverse types of activities are compressed - linguistic, perceptual, and cognitive. The language itself, its universality does not exist, we can see only the state of dialects, slangs, jargons, special languages, which like rats swirl one on top of another" (Deleuze \& Guattari, 1987, p. 13).

The logic of the root is the logic of rigid vector-oriented structures, whereas a rhizome is non-equilibrium integrity, largely analogous to non-equilibrium environments, which are studied by synergetics, which are not characterized by organizational arrangements and are distinguished by primary creative mobility. The source of transformation in this case is not the outside influences, but the inherent instability of a rhizome due to its energy-based potential of self-varying. A rhizome is "unstable, not unstable but rather metastable. It is endowed with potential energy". So it can be stated that a rhizomorphic environment possesses its own creative potential of self-organization, and in this respect it can be evaluated not as cybernetic, that is, subordinate to the commands of the center, but rather synergistic (Mozheiko, 2001, p. 657). For better understanding the essence of the study, it would be appropriate to consider the definition of the term "root".

Root (in Latin radix) is a subterranean axial radially symmetrical vegetative organ, capable of continuous growth in length and positive geotropism that anchors the plant in the substrate (soil), provides absorption and conduction of water with dissolved mineral substances to the stem, and leaves (Berehovyi et al., 1965). It may be of the following types: the main, which is formed from the germinal root of the seed. It has adventitious roots that develop on the ground or underground part of the shoots, lateral roots, which endogenously develop in the primary root, adventitious and lateral roots of the lower order. A root is inherently characterized by a radial symmetry (Biologicheskij slovar' on-line 2018), near the tip of the root (the primary root as well as lateral ones) a zone of root hairs is located. Anatomically, a root has a radial arrangement of vascular elements in the central cylinder. There are distinguished primary and secondary structures of the root. The size of the root is larger than the aerial part of the plant (Berehovyi et al., 1965, p. 275).

Thus, a computer as a standalone module beyond connections with others cannot be a rhizomatic formation, since it is designed as a specific hierarchical structure, where "power is granted to a memory or central organ" (Deleuze \& Guattari, 1987, p. 16). In our opinion, this linear formation is similar to a "radicle" in which vertical and linear connections are interwined. 
In order to consider the essence of the problem, it is necessary to interpret the definition of one more term "hyphae".

Hyphae (in Greek ' $\varphi \varphi$ ', a hypha - fiber, a Web) comprise a filamentous construction of fungi, consisting of many cells or containing a multitude of nuclei. In partitions between cells of the hyphae there may be holes (pores) through which the cytoplasm and organelles (including nuclei) flow freely from cell into cell; develop by apical growth; can intensively ramify; are able to join into longitudinal groups forming large (several meters long and several millimeters wide) strands - rhizomorphs (Kirk et al., 2008, p. 12, 78). Thus, hyphae have both horizontal and vertical connections that are nonlinear in contrast to the linear root, which reflects vertical and linear connections, as well as a rhizome with horizontal (interspecies) and planar connections.

As far as a global network is concerned, computer connections are not controlled with the keyboard or hands lying on it. However, they are managed by the "multiplicity of the user's nerve fibers, continuing as a multitude of coded and decoded combinations, into which the signals split and are transmitted into a multitude of channels" (Yemelin, 1999, see also 2004), and, finally, as a multitude of pixels, which glow on the screen and display current information. Secondly, taking into account the fact that in a rhizome, connection lines are more significant than connection nodes, we could say the same about the Internet, even though it would seem that the first impression could be indicative of the opposite, because the network connections are set up by switching from one computer to another. To put it metaphorically, the movement around the network is like "pilgrimage in the virtual world" (with all manifestations of nomadism) towards a definite purpose, although users do not change their location in space (in the real world).

A modern network is comprised of

"massively parallel computers with hundreds - or thousands - of tiny self-contained processors distributed throughout the memory field, all interconnected, and together far more powerful and more versatile than even the most sophisticated single processor" (Saco, 2002, p. 14).

A modern network is rather a hyphical model of a decentralized and anti-hierarchical structure developing both horizontally and vertically. It is a fundamentally open formation an environment (fourth-order cyberspace) with dominance of chaos, probability, integrity, etc.: everyone who has a computer, a modem, or get access to the telephone line or the Internet and Wi-Fi cable can potentially extend its boundaries (similar to hyphae, where both horizontal and vertical nonlinear connections are interwined).

Actually, a modern global network has no centralized station capable of monitoring information flows (or it just seems to us). Whereas

"in the past, all computers were huge mainframes with a single processing unit, solving problems in sequence, one by one, each bit of information sent back and forth between the CPU and the vast field of memory surrounding it" (Saco, 2002, p. 14).

Now the ways of transmitting information are not determined in advance and are unstable - they can vary depending on the functioning capacity of the lines; and regarding geography in some cases, the data routing may appear paradoxical. A virtual environment of 
the network has its own geography, and it matters nothing for the Net users which route the information goes, because the main thing for them is the possibility of direct contact with any destination and direct access to any Web page, regardless of its location in a global network.

Nowadays, the Internet is the most invulnerable among other well-known mass media. Let us recall the situation in Yugoslavia, when after the destruction of television transmitters, the channels of a global network became the main means of exchanging information with the outside world, since blocking the "Web" is much more difficult than bombing the antennas of the television centers. Therefore, the ideas of the American military to build up a global network have paradoxically recoiled on them: the principle of negligible rupture actually means impossibility of blockage, isolation and censorship in the global, ramified and multichannel "Web". (We can ascribe all this to hyphae but not to rhizomes).

Meanwhile, government learned to not only control but also block the network. Julian Dibbell (2012) refers to the events of January 28, 2011 night in Egypt, when the Internet was completely switched off as the reaction to the anti-government protest actions organized through Facebook and other networks. Another example, China built another "big wall", a firewall, which allows the government to block any sites. Consequently, network designers began to work effectively on making the Internet stable and dynamic, which would be able to resist the pressure from the outside of the state, government and corporations, as well as prevent the possibility of disconnecting some segments, ensuring the principle of freedom in the virtual space. At present, an alternative option is the creation of a free wireless community network topology, such as FunkFeuer. It does what providers are unable to do, namely, it transforms the user (the computer) from the final node into a transmitter, or in other words, it transforms ordinary Internet-users into independent providers (Dibbell, 2012, pp. 56-58).

We consider cyberspace as a constituent of hyphspace, in which a mutually beneficial collaboration and the exchange of information occur, with its active involvement and use in almost all kinds of human activity. For instance, special effects (cinematograph, television, video games), which appeal to people and are demanded by society, in the near future should become subjects of the study of psychology (an influence on the masses as well as on the individual), sociology, philosophy, communicativeness, etc., and should enhance advancement of new types of services: tourism, television, show business, etc. All this gives rise to new occupations (Knysh, 2017a, 2017b; Knysh et al., 2017), which require specialists with a non-standard type of thinking, who can combine creativeness and creativity with scientific achievements. Hence, it will require creating new workplaces, tools and instruments, etc. On the other hand, the information society accelerates "pushing" people out of reality (with overproduction of labour power and lack of workplaces) into a virtual environment (with many opportunities for artistic and creative development and realization of human capabilities, with a shortage of specialists, and the necessity to create new types of activity).

Therefore, particular emphasis should be laid on:

- Credibility that can be presumed as "a natural openness of some entities towards other entities functioning within the network" (Swinburne, 2014);

- Rapid exchange of information and interaction, because "[...] creative action involves cooperation of many entities, both in learning about the world and processing it. The network can make these processes much faster due to the rapid exchange of information” (Mazur \& Duchlinski, 2020, p. 61); 
- Involvement of various forms of art in life through education (Knysh \& Kochubey, 2017) and using bricolage strategies (Paek, 2019, p. 183);

- Changing the nature of labour: from mechanical routine to creative, intellectual and internally free work (Delyagin, 2003, p. 9) according to the concept of Karl Marx (2019):

a) Means of production. Earlier (from the classical to non-classical stages) a limited number of people owned the means of production, allowing a worker to use them partially, being unable to work on his own. Then at the post-classical stage, with the advancement of ICT, the worker owns the means of production since he is physically inseparable from them (they are information and knowledge in the worker's head, his skills, and his personal computer). At the same time, some part of the means of production, associated with other types of infrastructure, has become available to the public (it is the Internet). That is, a person got free from slavery and dependence on the people who previously owned the means of production and received, on the one hand, access to one part of the means of production, while inalienability, on the other one, made him an independent, equal participant in the production alongside its organizer and owner.

b) Labour power. If earlier (from the classical to non-classical stages) a worker was forced to sell his labour power to an empoyer, in exchange for wages, producing new goods, then at the post-classical stage, he freely hires out his labour for the share of the value he creates. Thus, the alienation of the worker from his labour power does not happen, because when the work becomes more creative, such alienation becomes technologically impossible.

c) Industrial relations. There is change from exploitation and coercion (from the classical to non-classical stages) to cooperation, creativeness and creativity (the postclassical stage) (Delyagin, 2003, p. 9).

Thus, these interpretations make it obvious that a combination of one part with another is not characteristic of rhizomes (rootstocks), as it has one starting point of development; it is the lines of communication and cross-references (communications) that turn the network into a global hyphspace rather than a locally separate (as a rootstock of a rhizome) group of computers. It is hyphae but in no way a rootstock of a rhizome (Deleuze \& Guattari, 1987) that comprise these lines of communication, since the aforementioned attributes are inherent only to it. In addition, the philosophers emphasized that in the environment within a computer network, subject-subject relationships between nomads (communicational) (rhizome - nomads) are formimg. We agree with the opinion that individuals who use external gadgets and devices for communication become neo-nomads (Attali, 1993, pp. 46-60). Some researchers name them homo mobilis (Beskrovny, 2004; Horuzhij, 2008; Amar, 2010), homo digitalis mobilis (Duivestein \& Bloem, 2013) or homo computus (Kutyrev, 2015, p. 102). There is an apparent discrepancy between the contemporary understanding of the term "nomad" and how it was interpreted by Deleuze and Guattari (1987), which can be explained by the level of the network development (let us take into account the time when they studied it), the nomads and sederants' involvement in it and their transformation into neo-nomads.

Eventually, third-order cybernetics transforms into fourth-order cybernetics, since it considers cyberspace as a component of hyphspace, that can be used as metaphorical abstraction, 
when it comes to philosophy and computer technology. Hyphspace represents a virtual reality that is a part of the noosphere; this is the world of a different nature, where users are actively involved in computer networks. Without changing their location, they are constantly on the move browsing Web pages, observing themselves and others, and therefore they can function as neo-nomads. That is, fourth-order cybernetics studies not only simple and complex systems and networks but also environments. Cyberspace, similar to a radix and a rhizome, extends its boundaries and becomes an integral part of hyphspace. Cyberspace, in contrast to hyphspace, includes processes both inside computers (radix) and inside a computer network (rhizome) with the involvement of an observer-nomad (an inventor, a technician), and hyphspace (hyphae) - with the involvement of the user - neo-nomad (who roams the Internet sites and observes himself and other users).

Thus, the network is a complicated neo-nomadic hyphical non-sustainable decentralized formation, which is constantly evolving both in horizontal and vertical planes and (for the time being, or it may only seem to us) nobody controls it. This network is self-born and continues self-developing (or it seems to us) as the informational and communicative nomadic environment of Deleuze and Guattari (1987), which, having changed in complexity, has transformed into hyphspace, and exists with at least one user - neo-nomad present as the subject of cognition.

In the environments that are developing in complexity, there appear certain preconditions for polyvariability of development and self-organization. In the future, it will probably make it possible to create virtual environments with predetermined parameters, as well as to control the processes taking place in them.

\section{Conclusions}

Having considered contemporary development of cybernetics, it would be appropriate to state that upgrade accompanies it: at the classical stage, first-order cybernetics studied observed systems (the object-object and subject-object paradigms) and observing systems (the subject-subject paradigm). At the non-classical stage, second-order cybernetics explored observed systems and the theory of observing systems (subject-object, subject-subject paradigms), which dealt with observers. At the post-non-classical stage, third-order cybernetics studied the systems ranging from observing systems (subject-subject) to self-developing environments (subject-polysubject) with the obligatory presence of a human (a nomad and a sederant) to hyphspace with a neo-nomad-observer or a user (users-neo-nomads) as the subject (subjects) of cognition in human-dimensional combined networks (the subject-polysubject environment) with increasing human-dimensionality (subject-subject). Eventually, this polyvariability of the control of the environment due to new discoveries in science will allow creating virtual environments with predetermined parameters, and also controlling processes that take in them, it means that we deal with fourth-order cybernetics based on hyphspace, which is a nomadic formation inside computer networks.

Consequently, hyphspace as metaphorical abstraction is a virtual reality - a component of the noosphere. This is a world that exists in computer networks with active involvement of observers-nomads (nomads roaming the Internet sites), who are subjects of cognition. 
Hyphspace at the present stage of cybernetics development is the basis for its subsequent (but not final) upgrade - fourth-order cybernetics.

Considering the contradictions between "physicists and lyric poets", that arose 20 years after the advent of cybernetics, we came to realize that at the classical stage of scientific development, scholars had to seek a solution to the problem. Therefore, at the non-classical stage, the processes of self-organization resulted in establishing interdisciplinary links between cybernetics and art, and at the post-classical stage a further interdisciplinary synthesis contributed to their mutually beneficial collaboration based on credibility, intraction, educational and brocolage practices, etc. A fundamental change happened in the nature of labor, the means of production, industrial relations and, accordingly, attitudes towards labour power. This list can be incomplete without such a phenomenon as human-dimensionality.

Obviously, cybernetics as a science is moving from cognition of human-machine systems to formations with increasing human-dimensionality, namely, human presence is growing the time of the stay, the speed of information retrieval, access to sites, number of users-neonomads, who persistently observe themselves and others on the network.

\section{References}

Amar, G. (2010). Homo mobilis. Le nouvel âge de la mobilité. Fyp éditions.

Attali, J. (1993). Na poroge novogo tysjacheletija. Mezhdunarodnye otnoshenija.

Berehovyi, P. M., Bilokin, I. P., Lavitska, Z. G., Polishchuk, L. K., \& Topachevskyi, O. V. (1965). Korin'. In I. P. Bilokin \& O. L. Lyna (Eds.), Slovnyk-dovidnyk z botaniky (pp. 275-276). Radyanska Shkola.

Beskrovny, I. (2004). Homo Mobiles: shag v storonu matritsy. E-Learning World, 4, 25-31.

Bevzenko, L. D. (2002). Sotsialnaya samoorganizatsiya. Sinergeticheskaya paradigma: vozmozhnosti sotsialnykh interpretatsiy. Instytut sotsiologii NAN Ukrainy.

Biologicheskij slovar' on-line. (2018). Kornevische. http://bioword.ru/K/K453.htm

Boltzmann, L. (1984). Izbrannye trudy. Nauka.

Burkov, V. N., \& Kondratyev, V. V. (1981). Mehanizmy funktsionirovanija organizatsionnyh sistem. Nauka.

Clausius, R. (1870). On a mechanical theorem applicable to heat. The London, Edinburgh, and Dublin Philosophical Magazine and Journal of Science, 4(40), 122-127. https://doi.org/10.1080/14786447008640370

Deleuze, G., \& Guattari, F. (1987). A Thousand Plateaus: capitalism and schizophrenia. University of Minnesota Press.

Delyagin, M. G. (2003). Mirovoy krizis: obschaya teoriya globalizatsii. INFRA-M.

Dibbell, J. (2012). Tenevaja set'. V mire nauki, 5, 55-61.

Duivestein, S., \& Bloem, J. (2013). The dark side of social media: alarm bells, analysis and the way out. LINE UP boek en media bv.

Foerster, Von H. (1979). Cybernetics of cybernetics. In K. Krippendorff (Ed.), Communication and control in society (pp. 5-8). Gordon and Breach Science Publishers, Inc.

Gibson, W. (1984). Neuromancer. ACE.

Gibson, J. J. (1950). The perception of the visual world. Houghton Mifflin Company.

Horuzhij, S. S. (2008). Problema postcheloveka, ili transformativnaja antropologija glazami Sinergiynoy antropologii. Filosofskiye Nauki, 2, 10-31. 
Kirk, P. M., Cannon, P. F., Minter, D. W., \& Stalpers, J. (Eds.). (2008). Dictionary of the fungi. CAB International.

Knysh, I. (2016). Filosofskyi dyskurs: rhizome versus radix versus hypha. Filosofija i Politologija v Kontekste Sovremennoy Kultury, 6(15), 157-164.

Knysh, I. (2017a). Merezhevyi filosofskyi dyskurs stosovno pryntsypiv: rhizome versus radix versus hypha. Praktychna Filosofija, 1(63), 53-62.

Knysh, I. (2017b). Suchasnyi menedzhment u konteksti LLL-osvitnioi paradygmy. Versus: NaukovoTeoretychnyi Chasopys, 2(10), 30-34.

Knysh, I. V., \& Kochubey, N. V. (2017). Tekhnolohichni aspekty stanovlennja novoyi osvitnioi paradyhmy. Informatsiyni Tekhnolohii i Zasoby Navchannja, 60(4), 181-194. https://doi.org/10.33407/itlt.v60i4.1600

Knysh, I. V., Kochubey, N. V., \& Niesvietov, O. O. (2017). Innovative enterprise structures: world and national experience. Science and Practice: Innovative Approach. Collection of Scientific Articles (pp. 275-277). Series: Economics and Finance. Les Editions L'Originale.

Kochubey, N. V. (2013). Sinergeticheskiye kontsepty v nelineynykh kontekstakh: seti, upravleniye, obrazovaniye. Palmarium Academic Publishing.

Kononov, D. A., Kulba, V. V., \& Shubin, A. N. (2004). Informatsionnoye upravleniye: printsipy modelirovanija i oblasti ispolzovanija. Trudy IPU RAN, 23, 5-29.

Kutyrev, V. A. (2015). Posledneye tselovaniye. Aletija.

Lefebvr, V. A. (2003). Algebra sovesti. Izdatelstvo "Kogito-Tsentr".

Lefebvr, V. A. (1973). Konfliktuyushchiye struktury. Izdatelstvo Sovetskoye Radio.

Lefebvr, V. A. (1965). O samoorganizuyushchikhsya i samorefleksivnykh sistemakh i ikh issledovanii. In M. F. Vedenov (Ed.), Problemy issledovaniya sistem i struktur: materialy k konferentsii (pp. 61-68). AN SSSR.

Lefebvr, V. A., Shchedrovitskyi, G. P., \& Yudin, E. G. (1965). "Estestvennoye" i "iskustvennoye" v semioticheskikh sistemakh. In M. F. Vedenov (Ed.), Problemy issledovanija sisyem i struktur: materialy $k$ konferencii (pp. 141-149). AN SSSR.

Lepskij, V. E. (2012). Refleksivnye aspekty v evolutsii predstavleniy ob upravlenii. Refleksivnye protsessy $i$ upravleniye (pp. 26-59). Izdatelstvo "Kogito-Tsentr".

Maksvel, Dzh. K. (1952). Izbrannye sochinenija po teorii elektromagnitnogo polja. GITTL.

Marks, K. (2019). Kapital. T. I, K. I.: Process proizvodstva kapitala. https://www.esperanto.mv.ru/Marksismo/Kapital1/

Mazur, P. S., \& Duchlinski, P. (2020). Credibility and creativity in network society. Creativity Studies, 13(1), 53-63. https://doi.org/10.3846/cs.2020.6585

Moore, G. E. (1965). Cramming more components onto integrated circuits. Electronics, 38(8), 114-117.

Morin, E. (2005). Metod: priroda prirody. Progress-Traditsija.

Motloch, J. L. (2017). Big history understanding of complexity, informatics and cybernetics. Systemics, Cybernetics and Informatics, 15(6), 54-60.

Mozheiko, M. A. (2001). Rizoma. In A. A. Gritsanov \& M. A. Mozheiko (Eds.), Postmodernizm: entsiklopedija (pp. 656-660). Interpresservis/Knizhnyi Dom.

Nejman, fon Dzh. (1960). Obshchaja i logicheskaja teorija avtomatov. http://db3.nsc.ru:8080/jspui/bitstream/SBRAS/9093/5/Neuman_Can_Turing.pdf

Paek, K.-M. (2019). The transformative potential of creative art practices in the context of interdisciplinary research. Creativity Studies, 12(1), 183-197. https://doi.org/10.3846/cs.2019.9701

Polonsky, V. (1968). Soznaniye i tvorchestvo. Izdatelstvo Pisateley v Leningrade.

Saco, D. (2002). Cybering democracy: public space and the internet. University of Minnesota Press. 
Shestakova, I. G. (2013). Noosfera: materializatsija idei kak kljuchevoj faktor sovremennogo progressa, Istoricheskije, filosofskije, politicheskije i yuridicheskije nauki, kulturologija i iskusstvovedenije. Voprosy teorii i praktiki, 3(29), 202-206.

Snow, Ch. (1970). Dve kultury i nauchnaja revoljutsija. In Y. B. Etingoff \& M. D. Millionshchikov (Eds.), Nauka i chelovechestvo (pp. 84-98). Znaniye.

Stepin, V. S. (2003). Samorazvivayushchiyesja sistemy i postneklassicheskaja ratsionalnost'. Voprosy Filosofii, 8, 5-17.

Swinburne, R. (2014). The existence of god. Oxford University Press.

Umpleby, S. A. (2016). Reviving the American society for cybernetics, 1980-1982. Cybernetics and Human Knowing, 23(1), 19-27.

Wiener, N. (1948). Cybernetics: or control and communication in the animal and the machine. The MIT Press.

Yemelin, V. (2004). Globalnaja set’ i kiberkultura: Rizoma i internet. Onjarlndepmhgl. http://emeline. narod.ru/

Yemelin, V. A. (1999). Informatsionnye tekhnologii v kontekste postmodernistskoy filosofii (PhD/Doctoral Thesis). Moscow State University, Russia.

\title{
KIBERNETIKOS ATNAUJINIMAS KŪRYBIŠKUMO PLĖTROS KONTEKSTE
}

\author{
Inna VASILIVNA KNYSH
}

\begin{abstract}
Santrauka
Autore siekia apsvarstyti kibernetikos atnaujinimą kūrybiškumo plètros kontekste šiuolaikiniame moksliniame diskurse. Pirmosios kartos kibernetika tyrinèjo stebimas sistemas, antrosios kartos kibernetika nagrinejjo stebejimo sistemas, o trečiosios kartos kibernetika analizavo subjektinę-polisubjekto aplinką - kibernetinę erdvę. Buvo gvildenami darbo pobūdžio, gamybos priemonių, gamybos santykių ir darbo jègos pokyčiai. Straipsnyje taip pat nagrinejjama „fizikų ir lyrikos poetų“ problema, kuri paskatino tyrèjus ieškoti galimų būdų išspręsti prieštaravimus. Tai sukūrè tarpdalykinius kibernetikos ir meno santykius neklasikinio etapo metu, o postneklasikiniame tarpsnyje tarpdalykinè sintezè nutiesẻ kelią jų abipusiškai naudingam bendradarbiavimui. Autorẻ vartoja šakniaerdvès sąvoką kaip metaforinę abstrakciją, skirtą virtualiai realybei (noosferos komponentas), egzistuojančiai kompiuterių tinkle (subjektinè-polisubjekto aplinka), apibrèžti. Dabartiniu šakniaerdvès raidos etapu tampa vèlesnio (tačiau ne galutinio) atnaujinimo - ketvirtosios kartos kibernetikos - pagrindu. Kibernetika, sudarydama tarpdalykinę sintezę su menu, pereina nuo žinomų žmogaus ir mašinos sistemų prie struktūrų, kurių atveju didẻja žmogaus dimensiškumo lygis ir nuolat auga vartotojų bei nomadų skaičius.
\end{abstract}

Reikšminiai žodžiai: menas, kontrolè, kūrybiškumas ir kūrybingumas, kibernetika, kibernetinè erdvé, šakniaerdvè, nomadai, „fizikai ir lyrikos poetai“, subjektiné-polisubjekto aplinka, atnaujinimas. 